\title{
Authentic Tibetan Tantric Buddhism and Its Controversial Terma Tradition: A Review
}

\author{
John Z. G. Ma ${ }^{1 *}$ \\ ${ }^{1}$ California Institute of Integral Studies, 1453 Mission Street, San Francisco, CA 94103, USA.
}

Author's contribution

The sole author designed, analyzed and interpreted and prepared the manuscript.

Article Information

DOI: 10.9734/ARJASS/2016/29736

Editor(s):

(1) Chang-Ho C. Ji, Department of History and Politics, La Sierra University, USA (2) Sheying Chen, Social Policy and Administration, Pace University, New York, USA.

Reviewers:

(1) Kyoo-Man Ha, Pusan National University, Korea. (2) William Owusu- Boateng, Kwame Nkrumah University of Science and Technology, Kumasi, Ghana. (3) Ruihui Han, Jinan University, China. Complete Peer review History: http://www.sciencedomain.org/review-history/16836

Mini-review Article

Received $27^{\text {th }}$ September 2016

Accepted $1^{\text {st }}$ November 2016

Published $7^{\text {th }}$ November 2016

\begin{abstract}
This short commentary reviews, on the one hand, the authentic formation and development of Tibetan Tantric Buddhism, an innovative branch that is featured by the transformation of negative emotions (NEs) to a valuable vehicle to reach the enlightenment of consciousness via achieving three different levels of kayas by experiencing three-stage practices; on the other hand, its problematic Terma tradition that claims to make use of six different ways in the transmissions of Buddhist teachings generation after generation. Both religious and scientific critiques are presented to this tradition in view of several aspects like the religious doctrine authenticity, historical veracity, and the formation of the tradition.
\end{abstract}

Keywords: Tantric Buddhism; Terma; transmission; consciousness; enlightenment.

\section{INTRODUCTION}

Featured by compassion, love, self-restraint and non-violence, Buddhism spread from India to Asia from the $3^{\text {rd }}$ century BC and all over the world in the following hundreds of years [1].
Buddhism has three different Schools [2]: (1) the Southern Hinayana or Lesser-Vehicle School; (2) the Eastern Mahayana or Greater-Vehicle School; and, (3) the Northern Tantrayana or Diamond-Vehicle School. Generally speaking, the historical developments of Buddhist doctrines 
were often in response to solving problems which had existed in earlier doctrines. Such an example was highlighted by the emergence of Mahayana in the $2^{\text {nd }}$ century A.D. out of the Theravada School, the teachings of which have been known as the "Pali-canon" given by the Buddha and collected at the Third Council after the Buddha's Mahaparinirvana, and described by the term, Hinayana, after around the 1st century A.D.

The Hinayana School exemplifies relatively a certain conservatism, and can be regarded as generally closer in doctrine and practice to ancient Buddhism as it existed in the early centuries B.C. in India [3]. One of the most important interpretations of this School suggests that Buddhahood can be achieved only by very few people like Gautama, except him the enlightenment is in fact unachievable for beings within this aeon; therefore, the ultimate goal of the Hinayana tradition lies in attaining the state of an Arhat by following the spiritual path via achieving the liberation for oneself, Nirvana, on an individual level after attaining the happiness by both "renunciation" and "perseverance" in the secular practice [4].

The Mahayana philosophy was developed by Master Nagarjuna in view of Sunyata (emptiness). While the new School fully accepted the traditional Buddhist teachings, it endowed the earlier doctrine with innovated interpretations, and consequently brought about profound consequences for the Buddhist practices involved. The most significant achievement was demonstrated by the recognition that, in addition to very few people, every sentient being, i.e., the being with a mind, is able to be fully enlightened to Buddhahood; and that the only thing to prevent the complete enlightenment is the failure to improve one's own actions and state of mind [5]. More importantly, the new School emphasized that the approach to reaching Buddhahood was primarily dependent of the altruistic wish and practice to lead all the sentient beings away from secular sufferings through their spiritual and flesh liberation (i.e., Nirvana) out of the cyclic existence in the sentient world; and, interestingly, with respect to this new philosophy, the Hinayana enlightenment for the self was nothing else but simply the fortunate by-product of the efforts to help all the beings [6].

This paper focuses on the third School, Tantrayana. This new School aims at solving the problem of how to effectively and efficiently reach Buddhahood for the secular human beings. Section 2 will introduce the authentic formation and development of this School. Section 3 will describe its problematic Terma tradition of which both religious and scientific critiques are presented. Section 4 will give a conclusion.

\section{TIBETAN TANTRIC BUDDHISM}

Although Buddhism disappeared in India in the $13^{\text {th }}$ century, Buddhist Tantra had continued to develop independently on the foundation of Mahayana, Mantrayana, and Vajrayana (including Kalacakra) branches. Since the 5th century, four types of tantric practice had come into being toward Buddhist enlightenment: (1) Performance Tantra; (2) Action Tantra; (3) Yoga Tantra; and (4) Highest Yoga Tantra, while, at the same time, Tantric Buddhism in Tibet, wellknown as Tibetan Tantric Buddhism, emerged with four major orders (the Nyingmapas, Kagyupas, Sakyapas, and Gelugpas) and the Dzogchen, as well as other syncretistic traditions [7].

The Tantric Buddhism stresses the acceleration on the way to be fully enlightened through a series of unusual practices to reach Buddhahood. It emphasizes the use of very subtle energies of the mind, of wind, and of the channels against a cluster of negative emotions (NEs), the dominant ones of which include Attachment (or greed), Aversion (or hatred), and Illusion (or ignorance), usually named as the Three Poisons [8]. The tantric practices employ a tantric construction named Mandala (circle in Sanskrit) which is embodied by five Buddha families. It is described as the energy grid to represent the constant flow of divine and demonic, human and animal impulses from the universe to interact in both constructive and destructive patterns featured by the following [9]: (1) the grid is three dimensional, in the sense that it locates the supreme deity (god, goddess, celestial buddha, bodhisattva, or enlightened tirthankara), the source of that energy and ground of the grid itself, at the center and apex of a hierarchized cosmos; (2) all other beings including the practitioner, are situated at the lower levels in energy or consciousness or being, emitting radiations downward and outward from the mandala's elevated center point; (3) four distinct qualities are included in the practices, namely, environment, body, objects, and deeds, where the $1^{\text {st }}$ quality refers to the mandala; the $2^{\text {nd }}$ one involves deity yoga; the $3^{\text {rd }}$ one means being surrounded by dakas, dakinis, and other enlightened qualities; and, the last one are the activities. 
Table 1. Macrocosmic and microcosmic elements in tantric practice

\begin{tabular}{|c|c|c|c|c|c|}
\hline Property & Level 5 & Level 4 & Level 3 & Level 2 & Level 1 \\
\hline Family & Buddha 3 & Vaira 2 & Ratna 4 & Lotus 1 & Karma 5 \\
\hline $\begin{array}{l}\text { Bodily Acts } \\
\text { Tathagatas }\end{array}$ & Vairocana & Akshobhya & Ratnasambhava & Amitabha & Amoghasiddhi \\
\hline \multicolumn{6}{|l|}{ Kayakarmam } \\
\hline $\begin{array}{l}\text { Verbal Acts } \\
\text { Vak karmam }\end{array}$ & Samantabhadra & Manjusri & Akasagarbha & Avalokitesvara & Vajrakarma \\
\hline $\begin{array}{l}\text { Mental Acts } \\
\text { Manokarmam }\end{array}$ & Acalavajra & $\begin{array}{l}\text { Trailokya-vijaya- } \\
\text { raja }\end{array}$ & Kundali Vidyaraja & Yamantaka & Guhyapada \\
\hline Consciousness & Amala & Alaya & Manas & Mano & 5-Organ senses \\
\hline Wisdom & $\begin{array}{l}\text { Dharma-Realm } \\
\text { Essence }\end{array}$ & $\begin{array}{l}\text { Great, Perfect } \\
\text { Mirror }\end{array}$ & Equality & Discrimination & Accomplishment \\
\hline Position & Center & East & South & West & North \\
\hline Season & Late Summer & Spring & Summer & Autumn & Winter \\
\hline Color & Yellow & Blue & Red & White & Black \\
\hline Element & Earth & Wood & Fire & Metal & Water \\
\hline \multirow[t]{2}{*}{ Body Organs } & Spleen & Liver/Gall & Heart/Pericardium & Lung & Kidney \\
\hline & Stomach & Bladder & Small Intestine & Large Intestine & Urinary Bladder \\
\hline
\end{tabular}

Compared to other Schools like Mahayana or Hinayana, the innovative aspect of the Tantric Buddhism lies in its transformation of the NEs to a vehicle which was claimed to be able to carry passengers with a faster speed to reach the full enlightenment of consciousness, Buddhahood, via three different stages successively in practice: (1) the foundation stage, (2) the path stage, and (3) the result stage. These stages represent achieving three different levels of kayas, namely, the truth body (Dharmakaya), the enjoyment body (Sambhogakaya), and the emanation body (Nirmanakaya). Such practices were believed to experience a complete cycle of reincarnation which is divided into three phases [10]: (1) the dying phase, corresponding to practicing the truth-body level; (2) the bardo phase, corresponding to practicing the enjoyment-body level; and (3) the rebirth phase, corresponding to practicing the emanation-body level.

In the practice, the displayed five Buddha families of the mandala provide a complete picture to [11] (1) understand the energy that pervades the neurotic world of ego-centered existence; (2) manifest the enhancement of the mind in the sacred world of awakening; and, the most importantly, (3) operate the five different aspects of enlightenment together in an integrated whole. Table 1 lists all the elements in the tantric practices related to the macrocosmic mandala in the mind transformation and corresponding microcosmic body organs [12].

However, considering that Buddhism is not an ahistorical unchanging tradition in time, space, and texts versus lived reality in the secular world, the tantric practice can be indigenized and simplified to different localized forms owing to the influences of different indigenous cultural backgrounds [13]. In the Everest Solu-Kumbu region of Nepal, for example, concise tantric rituals were held annually which were mixed with Tibetan Shamanism-like Bon religion, while still presenting the theme of the traditional Tantric practice. The innovations included [14]:

- Among the cluster of NEs including the three poisons, only the illusion (or ignorance) of human beings was suggested to limit their potential of imaginations and wills for the mind empowerment of transformation; thus, destroying the illusion is the highest form of magic.

- The compassion of all the Buddhas was personified specifically as the Lord of the Dance, named Garwang Tojay-chenpo, the deity of Mani-Rimdu whose infinite creativity is symbolized by dance.

- Trulshik Rinpoche was regarded to embody the Lord of the Dance and destroy the illusion in the tantric battles via dances with the malevolent supernatural forces of the universe at Thubten Chiwong Monastery each autumn.

- The three dimensional mandala was reduced to a design of a brightly colorful painting with sand, prepared painstakingly on a two dimensional plane grain by grain and mantra by mantra; however, the elaborated final product was destroyed to symbolize sending the mandala gods back to their realm; and, 
- Mental empowerment or spiritual sustenance was assumed to be able to be reached by taking man-made mini-pills which were considered to have absorbed the power of the god to help people, and therefore to be treasured and kept for taken in time of need. No doubt, these pills were treated as the symbols of the Nectar pills as introduced in Mahayoga, the early stage of the Highest Yoga Tantra.

\section{MYSTERIOUS TANTRIC TERMA TRADITION}

Among the Buddhist Schools, Tibetan Buddhism is distinguished by its tantric practices, as introduced in the above, which seem to be more efficient and effective toward full enlightenments relative to the life-long methods and techniques in other Schools. However, the most unusual aspect lies in the heritage of the tantric teachings. The tradition was initiated from the $8^{\text {th }}$ century when Guru Padmasambhava and Ye shey Tsho gyal concealed Termas (or, Gter mas), namely, the treasures of texts, relics and the transmissions of teachings, in the Tibetan and Himalayan landscape, dedicated for the discovery and retrieval by tertons (i.e., the treasure revealers) through a process of revelation in following centuries generation after generation [15]. The terma tradition is the richest and particularly prevalent in, and significant to, the Nyingma lineage [16]. In addition to this principal kind of "Earth" Terma, there are also two extra types of Terma [17]: one is called "Mind" Terma which was said to be discovered in the mind of the tertons; and the rest is called "Daknang" which is in general within the scope of the "Mind" type), but not necessarily claiming ancient origins as the pure visions appearing in the mind of realized masters.

It was claimed that there are four reasons which account for the existence of this mysterious tradition to suit various mental and physical desires, needs and capacities of people born in later historical periods after the various types of Termas buried earlier [18]:

- Doctrine shall not disappear. The reappearance of the Termas will make it possible for the teachings given in ancient time to avoid the fate of disappearance by maintaining their availability to people in later time.

- Instructions shall not be adulterated. the authenticity of the instructions in a lineage will be kept downward generation after generation if the teaching source is directly coming from the originals rather than going through the hands of different kinds of people in the lineage.

- Blessings shall not fade. Blessings from the originals will be kept intact by maintaining the purity and authenticity of the teachings in later time; and,

- Lineage of the transmissions shall be shortened. Because the Terton received the original teachings directly from Guru via the termas, none is between Guru in the $8^{\text {th }}$ century and a Terton later within the lineage, thus, the discovery of Termas shortens the lineage.

All of the canonical Termas were regarded to be transmitted to the Tertons through six stages of transmissions. Table 2 summarizes these six stages on account of what the bodies were supposed to be included for the purpose of communications, and how the transmissions were suggested to function in the communications.

In the Table, the first three stages were regarded as the common transmissions [19] via Mind, Indication, and Aural. The $1^{\text {st }}$ one was considered to happen between Buddhas by making use of spontaneous mind-mind communications without any verbal or physical expressions. The $2^{\text {nd }}$ one was assumed to take place between the knowledge-holders through symbolic expressions by verbal and physical indications, while the last one was known to occur between ordinary people through various means of the ear or relating to the sense of hearing, which had originated in Tibet with Guru Padmasambhava and his contemporaries and continued till the present day. It was claimed that the $1^{\text {st }}$ and the $2^{\text {nd }}$ ones can also exist among highly realized Tibetan masters even today.

By contrast, the last three transmissions were adopted as the uncommon ones [20]. Firstly, the Prophetic Authorization (or, the Prophetic Empowerment) implies that a disciple was prophesied by Guru to take rebirth at a specific future time and discover a particular Terma teaching as the Terton born at that future time of transmission. Secondly, the Transmission of Aspirational Empowerment (or the Mind-mandate Transmission) suggested that the teachings were concealed by Guru, through the power of aspirations via concentrating his enlightened mind in the essential nature of the minds of his disciples, or in the expanse of their awareness 
Table 2. Six transmission stages of termas: Bodies and functions

\begin{tabular}{|c|c|c|c|c|}
\hline Stage & Type & Transmission & Body & Function \\
\hline 1 & & Mind & Buddhas & Mind-mind coupling \\
\hline $\begin{array}{l}2 \\
3\end{array}$ & Common & $\begin{array}{l}\text { Indication } \\
\text { Aural }\end{array}$ & $\begin{array}{l}\text { Knowledge-holders } \\
\text { Ordinary people }\end{array}$ & $\begin{array}{l}\text { Symbolic verbal / physical signs } \\
\text { Hearing }\end{array}$ \\
\hline 4 & & Prophecy & Guru-Terton & Rebirth \\
\hline 5 & Uncommon & Aspiration & Guru-Disciple & Consciousness \\
\hline 6 & & Entrustment & Guru- Dakinis & Information delivery \\
\hline
\end{tabular}

states. If the teachings had been concealed in an external object or in the ordinary state of mind, they might be affected by changing circumstances. But they will remain stable until the time of discovery if concealed in the natural state of the mind. Lastly, the Entrustment to Dakinis declares that dakinis and protectors were instructed to protect the symbolic scripts of teachings which had been put in caskets and concealed in, e.g., rocks, lakes, sky, as devised by Guru Padmasambhava, and to hand them over in future to the right Terton, in addition to protecting properly the discovered teachings as well as the followers who practice them.

Nevertheless, the subject of Termas arose both religious and scientific critiques in the academia due to its uncertainties and/or preposterousness. These have been reflected by such dominant factors like religious doctrine authenticity, historical veracity, and the formation of the tradition in the transmission of Termas [21].

(1) Doctrine authenticity [22]. The focus of this emic critique lies dominantly in the authorship of the tantric scriptures. In Buddhist teachings of various schools, the sacred scriptures are generally believed to have been passed from master to disciple down to the present in an unbroken succession through transmissions involving direct human communications. They are usually defined as the spoken scriptures that are said to originate in the overt "well-stated speech" of the Buddha himself. However, in contrast to these scriptures which constitute the conventional Tibetan Buddhist canon, all of the Termas had been claimed to go underground in the absence of being spoken or overtly taught at all for a number of generations after the buddha's speech. This arbitrary claim inevitably leads to irrefutable challenges on the legitimacy of the scripture's author. As a result, Terma texts "may aptly be termed apocrypha, divergences between the Buddhist context and the Judeo-Christian one"; or, alternatively, they can be called "pseudepigrapha" in that their original authorship was attributed to a buddha, however, without the historical evidence.

(2) Historical veracity. Termas were suggested to have been hidden by Masters like Guru Padmasambhava in the $8^{\text {th }}$ century in the encoded form of contexts. However, is the text discovered centuries later the very same encoded fragment that Padmasambhava concealed for future generations? And, was it in fact "discovered," or, was it simply forged, more or less, by the discoverer himself due to intrinsic or extrinsic reasons during the excavation [23]? As a historical figure, the discoverer should be subject to demonstrating that he or she has the requisite realizations and attainments to formulate and transmit authentic Buddhist teachings before writing and codifying the Termas text for the final publication and presentation to the world. Otherwise, the lack of the demonstration not only makes it impossible to identify whether or not "the authority of the imputed original ... Treasure" had been "asserted in normative terms," but also put later generations of disciples or practitioners in an awkward situation to face with "the matter of qualifications" which "becomes tricky with regard to the Treasure discoverer" [23].

(3) Formation of the tradition. Etically, the Terma tradition myth can be noticeably traced back to the $8^{\text {th }}$ century upon the activities of Padmasambhava to introduce the tantric Buddhism into Tibet, though there had been a number of earlier concealing traditions in the indigenous teachings in, e.g., the Bon religion. In this myth, Padmasambhava was said to be a very central middleman to conceal Termas, the "most basically transmitted by a primordial buddha in a primordial pure land" [24], for the dissemination in such a predominate way that they would be discovered by various predetermined discoverers who would be incarnated at a specified future time by virtue of Padmasambhava's prophecy to "translate" their revelation into a form comprehensible to their contemporaries [25]. Concisely, it was claimed through the mythopoeic virtual powers of both 
Guru's and his enlightened disciples' minds that the transmission of these esoteric teachings took place [26]. No doubt, this tradition owns antiscientific absurdities in, for instance, Guru's biological GPS-emitter-like positioning accuracy [27], e.g., the prophesized reborn disciples are only within the Tibetan area and mostly in the Nyingma school; disciples' GPS-receiver-like mental resolution (e.g., translations express the originals comprehensibly in the absence of Guru's knowledge, experience, wisdom); not mentioning additional unrealities like the socalled "primordial" buddha and "pure land".

It deserves to mention that critiques were absolutely not limited only to these outstanding issues. They also came from academic views on additional alternative issues raised against Tarmas. Though out of the leading concerns, these views did make the controversies over the Terma tradition more conspicuous. For example, certain demonic spirits of the ancient time might be reborn as false Tertons to give apocryphal or fraudulent texts that look like Terma script [28]; in addition, new evidence indicates that the socalled Treasures, at least part of them, were rephrased, even plagiarized directly, from those Taoist classics introduced into Tibet in the $3^{\text {rd }}$ and $4^{\text {th }}$ centuries [29]. A detailed review in this aspect is beyond the scope of this short essay, and will be presented in a companion paper.

\section{CONCLUSION}

This short communication reviews the authentic Tibetan Tantric Buddhism and its controversial Terma tradition. It aims at contributing more to our understanding of such religious phenomena. Notice that this manuscript pays particular attention to the Terma tradition only, rather than other alternatives, due to the long lasting academic debates over this tradition.

Clearly, Tibetan Tantric Buddhism is a complicated Buddhist School. The complexity is demonstrated not only by its integrated perspective of the essence which embodies both the traditional source of the tantric philosophy and the indigenous practice of the tantric rituals, but also by the controversial Terma tradition which gives both common and uncommon transmissions of Buddhist teachings. Though the School aims at a more efficient and effective transformation to the full enlightenment of consciousness via achieving different levels of kayas, the usefulness of the tantric practice and the authenticity of its Terma tradition require further investigations.

\section{COMPETING INTERESTS}

Author has declared that no competing interests exist.

\section{REFERENCES}

1. (a) Omvedt G. Buddhism in India. New Delhi, Thousand Oaks, London: SAGE Publications. 2003;23-85.

(b) Anand. Essay on Buddhism in India. Available:http://www.history discussion.net/essay/essay-on-buddhismin-india/3144

(Accessed 24 July 2016)

(c) Buddha Dharma Education Association \& Buddha Net. Buddhism in East Asia. In: Buddhist world, Buddhist studies. Available:http://www.buddhanet.net/elearning/Buddhist world/east-asia.htm (Accessed 24 July 2016)

2. (a) Gethin R. The foundations of Buddhism. Oxford and New York: Oxford University Press. 1998;40.

(b) Kalu Rinpoche K. Profound Buddhism from Hinayana to Vajrayana. San Francisco: Clear Point Press. 1995;15.

(c) Sach J. Essential Buddhism: Everything you need to understand this ancient tradition. Avon: Adams Media Corporation. 2006;123.

3. Gethin R. The foundations of Buddhism. Oxford and New York: Oxford University Press. 1998;1.

4. Kalu Rinpoche K. Profound Buddhism from Hinayana to Vajrayana. San Francisco: Clear Point Press. 1995;16.

5. Gethin R. The foundations of Buddhism. Oxford and New York: Oxford University Press. 1998;Chapters 9,10.

6. (a) Rahula VDW. Gems of Buddhist wisdom.

(b) Skilton A. Asian studies, Buddha sasana, and a concise history of Buddhism. In: The three vehicles: A view on Buddhism; 2015.

Available:http://www.viewon buddhism.org/vehicles.html Accessed 25 August 2016

7. (a) Williams P, Tribe A. Buddhist thought: A complete introduction to the Indian tradition. London and New York: Routledge. 2002;204.

(b) White DG. Tantra in practice. Princeton and Oxford: Princeton University Press; $2000 ; 7$. 
(c) Tony. Introduction to the Buddhist path: Introduction to tantra. In: Dharma teachings at TBC, TBC introduction to Buddhism series; 2011.

Available:http://www.Tibetanbuddhist.org/i ntroduction-buddhist -path-introducti ontantra-pdf

(Accessed 24 July 2016)

8. White DG. Tantra in practice. Princeton and Oxford: Princeton University Press. 2000;3-38.

9. Williams $P$, Tribe $A$. Buddhist thought: $A$ complete introduction to the Indian tradition. London and New York: Routledge. 2002;192-244.

10. Tony. Introduction to the Buddhist path: Introduction to tantra. In: Dharma teachings at TBC, TBC introduction to Buddhism series; 2011.

Available:http://www.tibetanbuddhist.org/in troduction-buddhist -path-introduction$\underline{\text { tantra-pdf }}$

(Accessed 24 July 2016)

11. (a) Rockwell I. The five Buddha families. In: Lion's roar: Buddhist wisdom for our time; 2002.

Available: http://www. lionsroar.com/thefive-buddha-families/

(Accessed 24 July 2016)

(b) Williams $P$, Tribe A. Buddhist thought: A complete introduction to the Indian tradition. London and New York: Routledge. 2002;202-217.

12. Williams $P$, Tribe $A$. Buddhist thought: $A$ complete introduction to the Indian tradition. London and New York: Routledge. 2002;211. Table 1 in reference of figures 2.1-2.14 in: Maciocia G. The fundamentals of Chinese medicine $\left(3^{\text {rd }}\right.$ edition). New York: Elsevier. 2015;22-33.

13. Goodman W. Documentary on Tibetan Ritual. Film. 1987.

Available: http://www.nytimes.com/movie/ review?RES=9B0DEEDA123DF935A1575 1C1A96 1948260

(Accessed 24 July 2016)

14. (a) Goldberg M. Reviewed work: Lord of the dance, destroyer of illusion by FranzChristoph Giercke. American Anthropologist New Series. 1988;90(3):782-4.

(b) Wilmington M. Lord of the dance: A journey to Himalayas; 1987.

Available: http:// articles.latimes. com/1987-10-03/ entertain ment/ca-2784

1 tantric-dance

(Accessed 25 July 2016)
15. (a) Tulku Thondup Rinpoche. Hidden teachings of Tibet: An explanation of the Terma tradition of Tibetan Buddhism. Harold Talbott, editor. Boston: Wisdom Publications. 1986;10.

(b) Richen Terdzo. What is Terma? In: Shambhala Times. Holly Gayley. Editor. 2010;1.

Available:http://shambhalatimes.org/2010/ 07/01/what-is-terma/

(Accessed 29 July 2016)

16. (a) Tulku Thondup Rinpoche. Hidden teachings of Tibet: An explanation of the Terma tradition of Tibetan Buddhism. Harold Talbott, editor. Boston: Wisdom Publications. 1986;13.

(b) New World Encyclopedia contributors. Terma (Buddhism). New World Encyclopedia.

Available:http://www.newworldencyclopedi a.org/entry/ Terma (Bud dhism)

(Accessed 13 October 2016)

17. (a) Tulku Thondup Rinpoche. Hidden teachings of Tibet: An explanation of the Terma tradition of Tibetan Buddhism. Harold Talbott, editor. Boston: Wisdom Publications. 1986;57-93.

(b) Richen Terdzo. What is Terma? In: Shambhala times. Holly Gayley. Editor. 2010;1.

Available:http://shambhalatimes.org/2010/ 07/01/what-is-terma/

(Accessed 29 July 2016)

(c) Gyatso J. The logic of legitimation in the Tibetan treasure tradition. Hist. Relig. 1993;33(2):97-134.

(d) Gyatso JB. Drawn from the Tibetan treasury: The gTer ma literature. In: Tibetan literature: Studies in genre. Jackson R, Cabezon J. editors. Ithaca, NY: Snow Lion Publications. 1996;147-69.

18. Tulku Thondup Rinpoche. Hidden teachings of Tibet: An explanation of the Terma tradition of Tibetan Buddhism. Harold Talbott, editor. Boston: Wisdom Publications. 1986;62-3.

19. Tulku Thondup Rinpoche. Hidden teachings of Tibet: An explanation of the Terma tradition of Tibetan Buddhism. Harold Talbott, editor. Boston: Wisdom Publications. 1986;46-7.

20. Tulku Thondup Rinpoche. Hidden teachings of Tibet: An explanation of the Terma tradition of Tibetan Buddhism. Harold Talbott, editor. Boston: Wisdom Publications. 1986;63-5. 
21. (a) Gyatso J. The logic of legitimation in the Tibetan treasure tradition. Hist. Relig. 1993;33(2):97-134.

(b) Wheeler M. Keeping the faith alive: The Terton as mythological innovator in the Tibetan treasure tradition. Expositions. 2015;9.1:1-14.

22. Gyatso J. The logic of legitimation in the Tibetan treasure tradition. Hist. Relig. 1993;33(2):97-134.

23. Gyatso J. The logic of legitimation in the Tibetan treasure tradition. Hist. Relig. 1993;33(2):104.

24. Gyatso JB. Drawn from the Tibetan treasury: The gTer ma literature. In: Tibetan literature: Studies in genre. Jackson R, Cabezon J. editors. Ithaca, NY: Snow Lion Publications. 1996;151.

25. Gyatso J. The logic of legitimation in the Tibetan treasure tradition. Hist. Relig. 1993;33(2):98.
26. Tulku Thondup Rinpoche. Hidden teachings of Tibet: An explanation of the Terma tradition of Tibetan Buddhism. Harold Talbott, editor. Boston: Wisdom Publications. 1986;13.

27. Morrison L, Busch R. Global Positioning Systems (GPS) accuracy report. Wisconsin Department of Natural Resources, Madison, WI; 2001

Available: http://dnr.wi.gov/ maps/gis/ documents/gps accuracy.pdf (Accessed 30 July 2016)

28. Tulku Thondup Rinpoche. Hidden teachings of Tibet: An explanation of the Terma tradition of Tibetan Buddhism. Harold Talbott, editor. Boston: Wisdom Publications. 1986;154-155.

29. Zhu Y. Tibetan Buddhism and Taoism. Journal of Central University of Nationalities: Philosophy and Social Sciences (in Chinese). 2000;27(4):69-76. 